\title{
PROTEST AVOIDANCE: LABOR MOBILIZATION AND SOCIAL POLICY REFORM IN FRANCE*
}

\author{
Daniel Béland and Patrik Marier ${ }^{\dagger}$
}

\begin{abstract}
Students of public policy and social mobilization alike should pay more attention to the political strategies of protest avoidance. Distinct from traditional blame-avoidance strategies, protest avoidance occurs when elected officials, facing direct and nearly inescapable blame, attempt to reduce the scope of social mobilization triggered by unpopular reforms. In recent decades, successive French governments have introduced major, unpopular reforms in the field of public pensions, and because of the concentration of state power in France, avoidance of blame was nearly inescapable. Focusing on the 2003 pension reform, we argue that by dividing the labor movement through strategic bargaining, and by launching controversial reforms during or immediately before the summer holiday season, French governments reduced the scope of labor mobilization and facilitated the enactment of these proposals. Beyond the field of social policy, the concept of protest avoidance could shed new light on an understudied phenomenon: the strategies political actors pursue to reduce the scope of social mobilization against them.
\end{abstract}

Since the 1980s, students of social policy have depicted welfare state retrenchment as a "politics of blame avoidance" (Weaver 1986; Pierson 1994). When implementing cutbacks and restructuring social programs, policy makers from the right and the left attempt to reduce political risks stemming from the enactment of potentially unpopular reforms. Distinct from the logic of credit claiming that was dominant in the postwar era, the "new politics of the welfare state" is about escaping the popular blame generated by social policy cutbacks and restructuring. Although the concept of blame avoidance is useful for explaining the political logic of welfare state retrenchment, we argue that a careful analysis of social policy reform should consider a distinct, yet related, type of political strategy: protest avoidance.

Especially present in countries with single-party governments and politically active labor unions, protest avoidance complements the concept of blame avoidance by focusing on situations where policy makers, facing direct and nearly inescapable blame, attempt to reduce the scope of social mobilization triggered by unpopular reforms. ${ }^{1}$ Because painful reforms generally turn unions against the elected officials pursuing them, the need to reduce labor's mobilization capacity can be instrumental to the enactment and successful implementation of such reforms. Timing and "policy windows," as well as the geographical dimension of mobilization, are crucial aspects of the politics of protest avoidance, as mobilization capacity fluctuates over time and space. Two other forms of protest avoidance used in France and other countries are (1) strategic bargaining aimed at dividing the labor movement, and (2) the

\footnotetext{
* The authors would like to thank Karen Anderson, Fred Block, Sarah Brooks, Jean-Philippe Viriot Durandal, Stephen Kay, Angela Kempf, Christa van Wijnbergen, and three anonymous referees for their comments on previous drafts of this article, as well as Mahsa Hedayati for research assistance. Patrik Marier would also like to acknowledge the financial assistance of the Social Science and Humanities Research Council of Canada. Note that quotations originally in French were translated by the authors.

${ }^{\dagger}$ Daniel Béland is Associate Professor at the University of Calgary, Department of Sociology. Patrik Marier is Canada Research Chair in Comparative Public Policy at Concordia University, Department of Political Science. Direct correspondence to: Patrik Marier, Concordia University, Department of Political Science, 1455 boulevard de Maisonneuve Ouest, Montreal, Quebec, H3G 1M8, Canada, e-mail: pmarier@alcor.concordia.ca.
}

(C) Mobilization: An International Journal 11(3): 297-311 
framing of reform as inevitable. To increase their effectiveness, those in power can combine several different protest-avoidance strategies. ${ }^{2}$ Knowledge about social mobilization necessary to enact protest-avoidance strategies results from strategic learning processes that are distinct from the technocratic type of "social learning" commonly discussed in the policy literature.

In recent decades, successive French governments have introduced major-and generally unpopular-reforms in the field of pensions. This article demonstrates that the strategies used by these governments have been at least as much about avoiding protest and disruptive strikes by the labor movement as about escaping blame. This is because escaping blame is difficult when power is highly centralized, as in France. We argue that dividing the labor movement through strategic bargaining and launching controversial reforms during or immediately before the summer holiday season reduced the scope of labor mobilization and facilitated the enactment of the pension proposals. ${ }^{3}$ Such strategies have permitted some right-wing governments to impose their will on a pension system officially managed by employers and labor unions, commonly referred to as "social partners."

The empirical findings are based on the analysis of successes and failures to reform the French pension system since the late 1960s, with a specific focus on the 2003 reform. The story of contemporary French pension reform since the 1960s shows how protest avoidance can emerge as a significant aspect of modern welfare state politics. Protest avoidance is not restricted to social policy reform, however, and future scholarship could draw on this concept to analyze other political activities where avoiding protest is a concern for state actors.

\section{LABOR UNIONS AND WELFARE STATE RETRENCHMENT}

According to Pierson (1996), social policy retrenchment is a highly problematic task for policy makers who face strong opposition from new interest groups that emerge as a "feedback effect" of welfare state development. To reduce the risk of electoral backlash related to such opposition, politicians pursuing a retrenchment agenda frequently have mobilized blame avoidance strategies (Weaver 1986).

Because Pierson's work focuses on the U.S. and the U.K., he has largely neglected the dynamic conditions under which unions play an important role in retrenchment (Pierson 1994). For example, he rejects the validity of the power resource theory because the decline in union membership has not been accompanied by a similar decline in welfare benefits (Pierson 1994: 28-29). Against this view, scholars working on pension reform-including Piersonhave recently shown that "labor still matters" (Anderson and Meyer 2003; Béland 2001; Bonoli 2000; Culpepper 2002; Marier 2002; Miura and Palier 2003; Myles and Pierson 2001; Natali and Rhodes 2004). Labor's influence is particularly relevant in social insurance (Bismarckian) countries, where labor unions are often directly involved in trust fund management. As state-integrated social partners, unions identify themselves with the public pension system while framing ideological "property claims" over retirement benefits (Béland 2001). This identification means that unions can mobilize more easily against potential cutbacks, which are perceived as a direct attack against unions’ managerial role (Bonoli 2000).

In such an institutional context, labor unions still play a major role in the contemporary politics of pension reform. Mass mobilization and general strikes represent enduring political threats that may force the government in power to abandon retrenchment initiatives. Two protest episodes against retrenchment initiatives, the 1994 strikes in Italy and the December 1995 strikes that paralyzed France for several weeks, provide ground to this claim (Pitruzzello 1997; Natali and Rhodes 2004). With the use of massive strikes as a political weapon against politicians attempting to impose retrenchment efforts, unions can act as ideological veto players in the politics of pension reform (Béland 2001). 


\section{UNDERSTANDING PROTEST AVOIDANCE}

Although blame avoidance and protest avoidance frequently converge or even aggregate, there are clear distinctions exist between the two. On one hand, blame avoidance is about preventing, deflecting, or delaying blame. On the other hand, protest avoidance exclusively concerns strategies that militate against labor mobilization and mass protest. From this perspective, protest avoidance is about neutralizing concrete veto points that labor and social movements hold because of their capacity to "take the streets." In some contexts, for example, policy makers could accept direct political blame for unpopular measures while taking actions to limit the scope of street protest that may degenerate and complicate reform. Protest avoidance is thus analytically distinct from blame avoidance.

Yet, the concept put forward in this article is not an alternative to blame avoidance; and, more generally, neither is it an alternative to Pierson's theory about the "new politics of the welfare state.” The objective of this discussion about protest avoidance is to enrich this theory by stressing that, in some countries, protest is a political threat as significant as electoral loss, and that politicians must respond to this threat in a specific way. And, as blame avoidance is present in politics beyond social policy issues, protest avoidance is a type of political strategy that is not limited to welfare state politics.

The analytical distinction between blame and protest avoidance mirrors the one between routine and contentious politics. According to McAdam, Tarrow, and Tilly (2001), contentious politics, which involves widespread and potentially transgressive social mobilization, is different from routine politics, which engages through well-established bureaucratic, political, and electoral rules. While blame avoidance mainly concerns the reduction of political risks in routine electoral, political, and bureaucratic settings, protest avoidance is largely about preventing a shift from routine politics to the massive protests associated with contentious politics. And when this shift does occur, protest avoidance strategies promote the return to institutionalized forms of political struggle.

One example of the relationship between routine politics and blame avoidance is the role of the American Association of Retired Persons (AARP) in the United States (see Pierson 1996). Instead of using massive street protests to make its voice heard, the AARP is active in routine politics through methods such as mail campaigns, TV ads, and campaign finance. The institutionalized lobbying of the AARP creates political threats that are generally different in nature than the massive episodes of contention that can suddenly paralyze French society as a whole. If the preservation of social and economic order has long been a central concern for elected officials, protest avoidance illustrates how this traditional question is expressed in contemporary policy making. Although the concept of protest avoidance is not present in the current literature on social policy reform, the fact that social mobilization can affect the behavior of elected officials and impact welfare state politics has been described elsewhere. Authors focusing on the relationship between social mobilization and public policy imply that those in power take seriously the potential consequences of social disruption. For instance, when Piven and Cloward (1971) argue that the power of the poor lies in their capacity to mobilize and disrupt, it follows that policy makers will attempt to deny the poor the resources they need to protest effectively. The concept of protest avoidance gives a name to and clarifies the analytical contours of something essential that thus far has remained implicit in social movement and public policy literatures.

This concept is compatible with what has become the dominant theoretical perspective in the field of social movement and political protest studies: the political opportunity structure approach. The most basic assumption of this approach is that "exogenous factors enhance or inhibit prospects for mobilization, for particular sorts of claims to be advanced rather than others, for particular strategies of influence to be exercised, and for movements to affect mainstream institutional politics and policy.” (Meyer and Minkoff 2004: 1458). ${ }^{4}$ To a certain extent, protest-avoidance strategies form one of these exogenous factors. Protest avoidance 
focuses on how such strategies can inhibit prospects for successful mobilization stemming from specific political initiatives. Instead of focusing on how social movements and labor unions mobilize, the protest-avoidance perspective stresses the proactive behavior of political actors who have an incentive to reduce the potential scope of protest in order to secure the implementation of potentially unpopular reforms.

Like blame avoidance, protest avoidance results from the fact that policy makers are strategic actors who draw lessons from previous policy episodes. In the institutionalist literature, the concept of social learning defines how the evaluation of existing policy legacies influences future policy development. Criticizing the technocratic model of learning put forward by Heclo (1974), political scientists King and Hansen (1999) argue that learning processes are inherently ideological and political. But if drawing lessons from existing policies is a political process, officials in power seek to facilitate the enactment of controversial proposals based on strategic learning, rather than social learning. Social learning occurs when new policies build on existing ones. Thus, the evaluation of a program's economic and social consequences shapes subsequent policy decisions. By contrast, strategic learning takes place when elected officials constantly learn about political risks and opportunities related to timing, institutional structures, and the anticipated behavior of other social and political actors. Strategic learning thus enhances the officials "awareness of structures and the constraints/opportunities they impose, providing the basis from which subsequent strategy might be formulated and perhaps proved more successful” (Hay 1995: 201).

Underlying the learning and institutional mechanisms that shape political strategies, the concept of protest avoidance also emphasizes the importance of policy windows. As pointed out by Kingdon (2003), policy entrepreneurs have a short window of opportunity to implement the policy alternatives they support. If they fail to grab the occasion granted by events, such as the arrival of a new political coalition in power, external shock, and/or a shift in the national mood, they may end up waiting a long time before having another opportunity to advance their agenda.

The windows of opportunity affecting political strategies can be cyclical. First, within the British parliamentary system, for example, the aftermath of an election, commonly called the "honeymoon period," provides governments with effective opportunities to introduce unpopular measures. A government can claim that it has just received the mandate to enact these measures. Adding to this strength, the parties in the opposition are often disorganized following an electoral defeat, as they often are questioning their party leadership and the policies they advocate. The new government can also make use of the electoral cycle. Although unpopular measures were taken during the honeymoon period, it can hope that the electorate will have forgotten the unpopular reforms introduced three or four years before the elections, and will remember only more recent popular measures (Petry, Imbeau, Crête, and Clavet 1999).

In the French case, the impact of the electoral cycle is more difficult to evaluate. The possible presence of a political "cohabitation" between a president and a prime minister from different parties adds a twist to this dynamic. Mostly concerned with foreign affairs, the jurisdiction of a French president in domestic affairs during a period of cohabitation is extremely limited and nullifies any potential presidential "veto point" (Immergut 1992). ${ }^{5}$ Yet, this fragmentation of power has some influence when a prime minister seeks to challenge the president in an upcoming election. For example, Prime Ministers Edouard Balladur (1993-1995) and Lionel Jospin (1997-2002) were criticized for their inaction in the year preceding a presidential election as it became evident that they were going to run for the presidency. However, the electoral reform enacted in 2000 now ensures that the parliamentary and presidential elections coincide, meaning that the French electoral cycle should not be that different from the British one.

Second, in countries such as France and Italy, unions use strikes as a bargaining tool to obtain better benefits from their employers, and as a political tool to counter state policies. A series of unpopular measures can bring disastrous results for the government, as occurred in 
France in December 1995. Thus, in countries like France and Italy, a government seeking to introduce change that is opposed by unions must consider a high potential for strike activities.

Third, the literature on welfare retrenchment shows that one-party governments find it difficult to escape blame (Pierson 1993; Vail 1999). This follows from a majoritarian vision that emphasizes a concentration of power and policy-making capabilities (Powell 2000). In most countries with one-party governments, the executive is strong, visible, and highly centralized. Thus, considering that a highly centralized right-wing government introduced the last three major pension reforms, it is hard to embrace the concept of blame avoidance fully in the French context.

Although future research may reveal strategies not discussed here, at least four major types of protest avoidance can be identified. The first type occurs when policy makers decide to enact controversial proposals at a time when labor unions and/or potential social movements are not in position to fully mobilize their members and supporters. For example, they may enact a reform as the labor movement is facing strong internal divisions, or when many workers are on vacation and away from the cities where major protests take place. This protest-avoidance strategy has been used in France for three of the most important changes to the pension systems enacted since the 1960s, all initially strongly opposed by unions.

In the second type of protest avoidance, policy makers attempt to increase the geographical distance between themselves and the protestors or, at least, exploit geographical configurations to reduce protest. ${ }^{6}$ Organizing controversial political meetings and summits in remote areas that potential protesters would have difficulty accessing can diminish the scope and impact of street protests. For example, after the killing of a protester during the 2001 G8 meeting in Genoa, Canadian Prime Minister Jean Chrétien decided to hold the next meeting in Kananaskis, a remote resort area in the Rocky Mountains that was closed to protesters. The result was a sharp decline in the scope of social protest (Firby 2002). In contrast, geographical elements may favor protest in France where it is nearly impossible for French politicians to peacefully avoid major street demonstrations in Paris, because of the central location of the capital and the surrounding geographic configurations. Obviously, the capital cannot be moved. The centralization of the French economy, political institutions, and railroad system contributed to the success of the strikes of December 1995. In fact, the geographical dimension played a major role in producing a successful protest because these strikes affected so many citizens in the political and economic capital of France. For protesters, paralyzing Paris is one of the best ways to win over governments that attempt to impose fiscal and economic loss upon them.

The third type of protest avoidance occurs when governments bargain with labor unions and social movements, in order to divide them. This type of protest avoidance is widely featured in the politics in social policy reform. It is a strategy that can prove especially successful in countries like France, where the labor movement is already highly fragmented along organizational and ideological lines. The label of "new politics of the welfare state" cannot easily be applied to this strategy because the unions and the state have been struggling over their respective social responsibilities for many decades. Unions are also well aware of the government's attempts to divide them. In his work on pension reform, Bonoli (1997; 2000) argues that, in France, as in other European countries, policy makers have compromised with labor officials in order to guarantee the enactment of pension retrenchment while at the same time reducing the scope of union protest. In Italy, the 1995 "Dini reform" was grounded in a similar bargaining logic between elected officials and union representatives (Natali and Rhodes 2004). The empirical section, below, shows how strategic bargaining is an effective protest-avoidance mechanism, which can be combined with other strategies.

The fourth type of protest avoidance, which Cox (2001) calls "the social construction of the need to reform," can be a powerful strategy as well, because it is related to the important role of discourse and framing in political processes. Under this approach, political actors must frame the reforms in such as way as to vanquish the reluctance of the population to accept 
policy change. This is accomplished by shaping a reform path that takes advantage of shared symbols and representations (Cox 2001: 475). When supporting significant policy changes, political actors have to justify the need to reform, which can undermine the legitimacy of those actors who oppose the reform proposals of the day. This is particularly true of rightwing governments as they have long been associated with reforms that reduce the scope of the welfare state (Ross 2000). When opposition to controversial proposals takes the form of street protests, the social construction of the need to reform becomes a protest-avoidance strategy that political actors must pursue over a long period of time. The objective of this type of protest-avoidance strategy is to reduce popular support that potential protesters can gather. If the population perceives reform as "unavoidable," due to the activation of shared symbols and discursive frames, then attempts to mobilize against it may be regarded as futile-even illegitimate. ${ }^{7}$ This understanding of protest avoidance is in accord with Edelman's idea that state actors can "shape that cognitions of large numbers of people" while helping to "create their beliefs about what is proper; their perceptions of what is fact; and their expectations of what is to come" (Edelman 1971: 7). Although there is no hard evidence that the social construction of the need to reform public pensions had a decisive impact in France, the case study below briefly explores the discourse of French political actors that attempted to make reforms appear unavoidable.

\section{LABOR POLITICS AND PENSION REFORM IN FRANCE}

Since the 19th century, the French labor movement has remained highly fragmented among organizational and political lines (Karila-Cohen and Wilfert 1998). Moreover, state building in France has involved a stark centralization of power (Rokkan 1999). Thus, most unions have adopted a pugnacious attitude towards the state (Lipset 1983). As a consequence of a strikingly asymmetrical distribution of power between divided unions and a centralized state, modern corporatism and social democracy never became dominant patterns in France (Keeler 1985; Birnbaum 1988). In contrast to the situation prevailing in Sweden or in Germany, confrontation between the state and labor unions, rather than collaboration, is the most common practice in France, and the strike has long represented one of the only political tools in the hands of weak unions paradoxically seeking state protection and institutional autonomy from the state. For these reasons, the political strike became the most central element of French labor's "repertoire of contention" (Tilly 1986). As a result, unions have supported the constitution of a social insurance system "outside the state" (Ashford 1986). Further accentuating the fragmentation of the social security system, attempts to universalize it also were opposed by the middle class and the self-employed because having a universal system meant an extension of the risk pool they would have been financing (Baldwin 1990).

Before analyzing the features of the French social insurance system, it is important to recognize that this apparent weakness of the French labor movement concerns the private sector, where unionization rates are extremely low on average. Furthermore, unionized private sector workers are mostly represented in the Confédération Française Démocratique du Travail (CFDT). It is ironic that, partly because of the state's strength in France, public employees tend to dominate the labor movement because unionization rates are higher in the public sector (approximately 20 percent) than in the private sector (approximately 5 to 6 percent). ${ }^{8}$

Moreover, the public sector is perceived as a crucial component of French society rooted in a universalistic model of state sovereignty. Universalistic claims paradoxically justify occupational privileges (Howard 1998). Although the neoliberal turn of the 1980s undermined the traditional prestige of state bureaucracy, civil servants still enjoy some prestige in France. If the population is split with regards to the level of trust given to them, this relative support is very strong once we consider that political parties are distrusted by 83 percent of the French population (European Barometer 57, 2002). Attacks against the occupational status 
of civil servants and other public employees are sometimes understood as a threat against the public service itself and the integrity of the nation as a whole. The mobilization of civil servants and other public employees is sometimes understood as a counterweight to elected officials who would choose to undermine the status of the state and its employees, who depict themselves as the agents of universalism and equal citizenship.

French strikes, especially public sector strikes, have an immediate political significance and are not imagined as mere tools of collective bargaining (as in North America, for example). Yet, French strikes inevitably deal with the specific interests of occupational groups, particularly civil servants and employees of public enterprises such as Electricité de France (EDF) and the Société Nationale des Chemins de Fer (SNCF). Many strikes also deal with pension-related issues, because union officials and their allies have depicted them as an "indirect wage" related to particular occupational status. This perception is linked to the fact that the French pension system is fragmented along occupational lines: specific professional categories have their own public pension schemes (Palier 1999). ${ }^{9}$

Some historical background is necessary to understand more fully labor's identification with public pensions. Between 1945 and 1967, only labor unions were authorized to participate in the management process of the pension scheme covering private sector workers, the so-called régime général. ${ }^{10}$ This reality reflected the growing strength of labor unions in the immediate postwar era (Guillemard 1986). Following the creation of the Fifth Republic in 1958, the tables turned. The political power of the left strongly declined and the management of pensions by unions became a point of contention. Already in the early 1960s, the state had become more involved in the administration of pensions and many reports underlined large deficits in social security, leading the government to pay closer attention to this issue (JoinLambert 1997). The year 1967 began with a key debate concerning the inclusion of farmers and other independent workers into the régime général. Georges Pompidou, then France's prime minister, waited until mid-August to reorganize social security despite protest from union officials, who could hardly mobilize their members during summer vacation. This "summer strategy" proved successful. Although retrenchment was not an issue at stake, this reform restructured the managerial system of the French pension in a significant manner and removed the monopoly enjoyed by unions. Called paritarisme (Friot 1998; Guillemard 1986), this system has never been entirely acknowledged by the more radical unions, Confédération Générale du Travail (CGT) and Force Ouvrière (FO), who claim to be the only true defenders of "conquered rights." Restricting the legitimacy of these boards was the governmental decision to abolish existing "social elections" and replace them by nominations by each of the social partners.

\section{THE POLITICS OF PROTEST AVOIDANCE IN FRENCH PENSION REFORM}

Since the 1980s, the rise of neoliberalism, short-term financial concerns, and growing demographic fears have increasingly transformed massive pension retrenchment into a serious, if unpopular and risky, option for policy makers in France (Renard 1999). Yet, contrary to the prediction made by the former Prime Minister Michel Rocard (1988-1991) that reforming pensions could break a government, Prime Minister Balladur successfully introduced a significant pension reform without effective opposing mobilization. The 1993 episode, explained below, supports the concept of protest avoidance, especially as it is related to the timing of the reform and strategic bargaining with labor officials.

Following an impressive electoral victory in April 1993, the Balladur government wasted no time in tackling the issue of pension retrenchment and convened multiple meetings with the unions (Vail 1999). The government opted first to send flowers to the social partners by introducing a goodwill measure in June, which was followed by the vase in mid-August during the summer holiday season. The Fonds de solidarité vieillesse (FSV) came to life in 
early June to finance solidarity (social assistance) measures for the régime général (Ruellan 1993). ${ }^{11}$ Even though this measure did nothing to reduce the costs of pensions, it nonetheless provided new sources of financing.

Following turbulent meetings in mid-June with the unions, the government went ahead with other aspects of its plan and introduced the first retrenchment measures on pensions. First, along with the legislation creating the FSV, the government included legislation indexing pensions on price, a measure that would have to be renewed in five years by decree. This made into law a practice that had occurred since 1987 (Ruellan 1993: 919). Second, the length of the contribution required in order to obtain a full pension was increased from 150 quarters (37.5 years) to 160 quarters (40 years) progressively starting in 1994 . The reform would be implemented over a period of ten years, by adding a quarter every year until 2003. Finally, another measure tackled the period under which the pension is calculated, which was based on the worker's 10 best years. The number of years was increased to 25 progressively, by adding a year, starting in 1994, for the next fifteen years (or until 2008).

Contrary to expectations, the reform generated neither a widespread backlash against the government, nor a strong negative reaction from the social partners. Three key reasons explain the lack of mobilization against the Balladur government. First, the timing of the reform reduced the scope of protest. By introducing the reform prior to the holiday season, Balladur activated the strategic lesson from his days as conseiller social (social advisor) to Prime Minister Georges Pompidou in 1967, when the major management reform of the pension system was introduced successfully. Union representatives from both CGT and FO, two unions strongly opposed to the reform, stressed that they could not mobilize effectively their members at this specific time of the year (Marier 2002).

Second, Balladur was able to split the unions by obtaining the support of the CFDT, the leading union for private-sector workers. This support was obtained by creating the FSV (Bonoli 2000; Natali and Rhodes 2004; Vail 1999). The enthusiasm of CGT and FO members became limited, due to the CFDT stance and the lack of strong representation in the private sector, a critical element because public sector workers were not affected by the reform. Finally, Balladur muted the protest from the Socialists, who were entangled in internal conflict following their worst electoral defeat, by using and implementing measures advocated by the white paper on pensions produced by then-socialist Prime Minister Rocard in 1990.

Just months following the election of Chirac as president, on May 7, 1995, where he promised to tackle the "social fracture," France entered a severe economic recession resulting in speculative attacks on the franc and public doubts that it could join the Economic and Monetary Union (EMU) (Pitruzzello 1997). During the summer of 1995, the Juppé government admitted that it was studying proposals to reform the social security system. He met the social partners in September and talked about the unfairness of the pension system with civil servants having to contribute "only" 37.5 years for a full pension as opposed to the 40 years required of private sector workers. Following a meeting with Chirac on November 12, unions were informed on a nonofficial basis that pension reform was left off the agenda (Bonoli 2000: 143). Surprisingly, even to some of his own ministers, Juppé announced the most drastic changes to the whole social security system on November 15.

With regard to pensions, Juppé announced that the Parliament would have a larger role in budgetary decisions related to social security. Also, a new fund (caisse) was introduced to cover public sector workers so that those finances would no longer be lost in the general budget of the state. The most controversial aspect of the plan was the lengthening of pension contributions for public sector workers from 37.5 years to 40 years, in line with those in the private sector following the Balladur reform. Despite the way the plan was introduced and the severity of the changes, the opposition and the social partners were very slow to react. Unions divided rapidly with the announcement that the CFDT supported the direction of the reforms, but protest from rank and file moved it into the protest camp. With high stakes in the administration of health schemes and a strong membership within the civil service, FO asked for the 
immediate removal of these measures. The CGT had similar views. Starting with railway workers and followed closely by subway workers, a strike movement gathered momentum at the end of November and climaxed on December 12 with one million to two million protesters in the streets, and with a majority of the French population supporting the strikers (Mouriaux and Subileau 1996). This protest forced Juppé's hand, and he had to shelve his plan for pension reform.

It is worth noting why the pension elements of the Juppé plan failed. First, the timing of the government could not have been worse in terms of cutting social benefits to civil servants, especially those employed by the railway (SNCF) and public transit systems (most notably, the Régie autonome des transports parisiens or RATP). The government was already struggling to negotiate with the unions for a new strategic plan to reduce the deficits of these public enterprises. This bargaining seemed essential because, in recent years, labor unions in these two public companies had launched 80 percent of all strikes. What is more, by announcing the plan in November, it was easier for union officials to mobilize the workforce and cause chaos in Paris. Media reports indicated that it took four to five hours for people to reach their workplace as a result of the chaos. Thus, the geographical dimension played an important role in accentuating the disruptive impact of the street protest. The entry of the SNCF and RATP into the protest movement caused a high level of nuisance and disruption, particularly in such a centralized society where paralyzing Paris often means paralyzing the country as a whole. This is especially true because Paris is the core node of the French railway network.

Second, by tackling the whole social security system at once and by refusing to launch strategic bargaining with labor officials, Juppé provided unions a golden opportunity to mobilize and reconcile their differences. Every major union but the CFDT had something to oppose, including the measure to reduce their role in the management of social security. This movement even featured a novelty in terms of cooperation: an alliance between FO and CGT, two unions that had long been split over their communist allegiance. Finally, the Socialists were muted again because they had previously favored similar measures. Their leader, Lionel Jospin, eventually criticized the Juppé method.

\section{The 2003 Pension Reform}

After the 1997 legislative victory of the left, the Jospin government adopted a cautious approach to pension reform. During his mandate (1997-2002), the prime minister ordered the preparation of several pension-related reports, yet he postponed any significant pension reform that could have eroded his support within the labor movement. All attempts to demonstrate the need for reform were countered by reports sympathetic to unions.

The sweeping victory of right-wing parties in the 2002 French presidential and legislative elections created a new window of opportunity for pension retrenchment. During this campaign, President Chirac and his allies embraced a right-wing platform, centered on "zero tolerance" and the war on crime, instead of advocating generous social programs, as they had done in 1995. From that perspective, the discourse of the right proved more coherent in 2002 than it did in 1995.

Early in 2003, the new right-wing government of Prime Minister Jean-Pierre Raffarin hinted that it was studying reform scenarios. In mid-April, Civil Service Minister Delevoye and Social Affairs Minister Fillon met with the social partners to open discussions on the subject of pension reforms to introduce legislation. They presented a text that contained a draft of possible reforms to the pension system. The so-called régimes spéciaux were left out of the discussions. Among the key proposals presented was an extension of the contribution period in the public sector scheme so that a contribution period of 40 years would be required in both private and public sectors by 2008. The government also planned to abolish the measure granting full pensions to women who had fifteen years of contributions and three children. Still, with regards to public sector workers, in order to discourage early retirement the 
government was planning to add a three percent penalty per noncontributed year and add up to three percent for each supplementary year worked after the age of 60. As a compromise, the government presented a plan to reduce the ten percent penalty for each year retired prior to age 60 , in order to harmonize the penalties.

The response from the unions was swift and decisive. As expected, the more radical unions such as FO, CGT, Union Nationale des Syndicats Autonomes (UNSA), and Fédération Syndicale Unitaire (FSU) stressed the social regression apparent in the measures and condemned them as being financially motivated. The CGT claimed the measures would result in a 20 percent loss of retirement income, while FO's leader said the proposal necessitated an immediate strike. What was surprising, however, was the opposition of the CFDT, which had already approved the orientations of the governmental policy on retirement in March. It argued that the countermeasures were insufficient and that most of these measures represented short-term solutions. Its leader stated, "the total does not add up” (Le Monde April 18, 2003). The increasingly powerful employers' lobby (Mouvement des Entreprises de France) was happy with the orientations of the reform, because it avoided contribution hikes, and urged swift action.

Despite the combined opposition to the reform among the unions, organizing a common action proved difficult. The more radical FO and, to a lesser extent, CGT both promoted a hard line by requesting the withdrawal of the reform. For their part, the reformist CFDT and the white-collar union Confédération Française de l'Encadrement-Confédération Générale des Cadres (CFE-CGC) remained optimistic that a compromise could be worked out with the government. The unions finally agreed to strike on May 13 and presented a common text that included a line on the need to reform pensions at the request of CFDT (Le Monde April 24, 2003). Two independent opinion polls conducted a few days before the May 13 strikes provided them with an additional lift as more than 60 percent of the population proclaimed their support for the protest activities organized by the unions (Le Monde May 12, 2003).

One week prior to the strikes of May 13, Raffarin remained defiant, stating publicly that "the street can give its views, but the street does not govern" (Le Monde May 8, 2003). A publicity agency was hired to sell the reform to the public. A full-page newspaper ad was published and flyers were sent to French homes.

The May 13 strikes sent a chilling message to the government. With more than 60 percent of workers on strike (compared to 30 percent in 1995) and one to two million citizens in the streets, the opposition to the reform proposals gathered strength. Launching a strategic bargaining blitz, Fillon contacted the CFDT and CFE-CGC, and a negotiation session lasting more than ten hours occurred between the parties (Le Monde May 14, 2003). Following the promises on the part of the government (1) to increase the minimal pensions for low wages from the proposed 75 percent of minimum wage to 85 percent; (2) to increase pensions beyond inflation; (3) to increase pensions for the so-called pluri-pensionnés (those who belong to multiple schemes); and (4) to solidify the commitment to grant full pensions to those who started contributing at the age of 14,15 , or 16 with a full career, ${ }^{12}$ the CFDT and CFE-CGE announced their support of the reform on May 15. The CFTC did not formally endorse the plan, but stopped its active opposition (Le Monde July 23, 2003). Strategic bargaining initiated by Fillon divided the labor movement and reduced the potential scope of protest.

More radical unions (FO, CGT, UNSA and FSU) called for continued actions and planned other demonstrations. The most significant action occurred on June 3 when 450,000 to 1.5 million citizens participated. However, the strike rate had decreased by half, compared to May 13. Subways and trains continued to operate as a result of this weaker mobilization. Another important day of action was June 19, when demonstrators numbered between 116,000 and 320,900 individuals, but with little effect on many services such as public transportation. This would be the last significant action by union members to stop the reform.

In the meantime, opposition MPs sought to disturb the legislative process by introducing thousands of amendments (Le Monde July 23, 2003). It is ironic that these actions might have 
helped the government because they delayed the adoption of the bill in Parliament until later in the summer. Unions were unable to maintain their opposition as the number of protesters declined continuously throughout the parliamentary procedures. The bill was finally adopted on July 24, a time of the year when a significant portion of potential protesters take vacation. After the failure of a Socialist appeal to the Constitutional Council, the bill became law on August 22.

Protest avoidance provides a strong explanation of the 2003 reform. First, as the time for summer vacation approached, it became more and more difficult for union officials to mobilize their members. As stated by FO leader Marc Blondel just before the last day of large-scale protest on June 19, 2003: "It's almost certain that this mobilization will be a protest of activists rather than a [massive] popular protest because paid vacations are approaching, and unions have repeatedly asked workers to mobilize" (Le Monde June 19, 2003). This explains why one of the largest unions in the public sector (the FSU) proposed to relaunch the protest once students had returned to school in September (Les Échos June 26, 2003). While the threat of disrupting classes maintained pressure regarding education reforms, the protest momentum about pension reform had vanished.

Second, by reaching an agreement with three unions (CFDT, CFE-CGC and CFTC), the government succeeded in splitting the movement. Membership in these three unions is mostly concentrated in the private sector, and the governmental offers granted them benefits in exchange for supporting a reform affecting mostly public sector workers. The movement was also further divided because "special regimes" (including those for railroad and urban transportation workers) were not affected. Thus, SNCF and RATP workers, the key groups behind the protest of 1995, did not have strong reasons to strike.

\section{Discussion}

Facing the threat of massive pension-related protests, French policy makers have attempted to reduce the mobilization capacity of labor unions by employing protest-avoidance strategies. First, besides the 1993 and 2003 reforms discussed above, the 1967 pension reform that integrated business representatives within public pension boards is a stunning example of what could be labeled the "summer strategy" of French policy makers. This strategy is based

Figure 1. Average Number of Days of Striking recorded in France 1997-2001

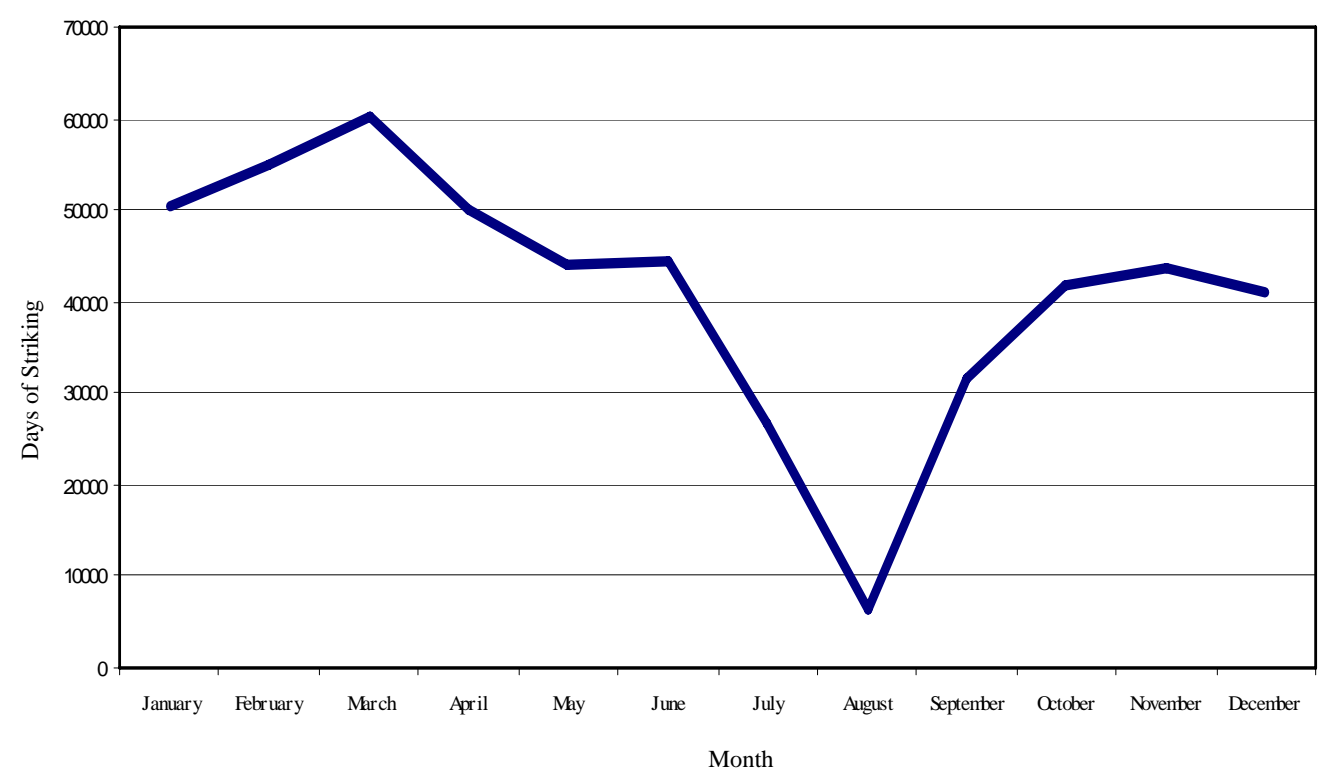


on the fact that most French workers, especially those of the public sector, take their vacation in July and August, and that union workers seldom mobilize during these two months months. Even though the number of legislative initiatives also declined, we demonstrate that key social measures were adopted near or during the holiday season. As evidenced by figure 1 , there is a sharp decline in the number of days of striking during the summer months, especially in August. During this month, averages of 6,500 total days of striking have occurred. This represents less than 1.3 percent of all days of striking recorded annually. This is in stark contrast with other months, especially winter ones, when the average is above the 40,000 mark.

Second, as in the French case, another aspect of protest avoidance is important in explaining policy outcomes: the presence or the absence of strategic bargaining with labor officials. When policy makers fail to reduce labor opposition and divide potential protesters through strategic bargaining and quid pro quos, massive strikes can have dramatic consequences and even force elected officials to abandon their proposals. The fate of the 1995 Juppé plan illustrates how the failure to adopt the right combination of blame- and protestavoidance strategies can turn the street against elected officials. It also demonstrates the negative consequences of failing to learn from earlier, successful strategies used to impose unpopular reforms. Contrary to the 2003 reform, which was enacted during the summer months and after strategic bargaining with the unions, as in the Balladur reform, Juppé stubbornly and forcefully pushed his plans ahead with apparently disastrous results (Vail 1999).

Third, despite incessant ideological attempts to frame the need to reform and make opposition appear illegitimate (Renard 1999), governments have not been able to rally the French population. There is strong evidence that, in other countries, framing processes can reduce opposition to, and mobilization against, specific reform proposals (Cox 2001). From that perspective, the construction of the need to reform, by making opposition look illegitimate, represents a possible form of blame avoidance. ${ }^{13}$ Yet, in the French case, there is little evidence that the discourse of right-wing politicians depicting pension retrenchment as "unavoidable" made a difference. On the contrary, at least in the short term, this argument has hardened opposition against the government resulting in the construction of a left-wing counterexpertise and discourse on pension reform. Only time will tell if such discourse will have a long-term effect on prospects for pension retrenchment.

Finally, the successful enactment of the 2003 reform shows that strategic learning processes took place within the French right. In a newspaper interview, Bernard Accoyé, an influential official from the ruling party (UMP) argued that everyone on the right "remembers 1995. This motivates us to remain cautious" (Le Monde May 5, 2003). Excluding Juppé from the government, adopting - at least in public — a conciliatory attitude, and launching the reform at a different time of the year helped the Raffarin government distinguish itself from the ill-fated Juppé government and its unsuccessful attempt to reform public pensions. Rejecting the "reform overload" logic of the Juppé plan, which concerned both pensions and health care, the Raffarin government adopted a far more limited reform agenda that facilitated the full enactment of the 2003 pension legislation.

\section{CONCLUSION}

Our analysis establishes that, in France, elected officials have made systematic efforts to avoid labor's disruptive strike activities. As shown above, the three most important alterations to the pension system established after World War II $(1967,1993,2003)$ occurred in the middle of summer, a time of the year when potential strikers take vacation. Consequently, a cyclical policy window exists in the summer following legislative elections. Yet, far from formulating a monocausal argument, this article also focuses on the central role of strategic bargaining and framing in the French politics of protest avoidance. 
For politicians, bargaining with unions is not necessarily a way to reach an agreement with all social partners, but instead a way to divide the labor movement and reduce the potential scope of protest stemming from measures these politicians seek to impose. The right-wing parties were successful in silencing the socialists by adopting a position they had earlier defended. However, due to the lack of formal ties between socialists and unions, this strategy proved ineffective in reducing the scope of street protest. Regarding the French case, this article underlines the geographical aspect of protest (i.e., the status of Paris as a site of power and contention), the rather unsuccessful attempt to depict pension reform as inescapable, and the casting of opposition as illegitimate.

Beyond the French experience, this article contributes to the international debate concerning the nature of the "new politics of the welfare state." Protest avoidance deserves attention because it affects policy outcomes while being analytically distinct from blame avoidance. Although scholars have started to systematically analyze the relationship between social mobilization and social policy reform, protest avoidance remains an understudied phenomenon that is present where widespread social mobilizations represent a major source of concern for policy makers. In Italy too, governments have attempted to reduce the scope of social protest stemming from unpopular social reforms (Natali and Rhodes 2004). In the future, students of social policy would be well-served to extend the analysis of protest avoidance beyond the French case.

The protest avoidance concept could also prove useful beyond the study of labor mobilezations in welfare state politics. First, in the field of social policy, protest avoidance may extend beyond the prevention of labor protest and concern the political neutralization of senior organizations and specific social movements. Second, protest avoidance represents a set of four main strategies (timing; geographical separation; strategic bargaining; and the construction of the need to reform) that transcend the domain of social policy. When certain political decisions prove unpopular and trigger social unrest, political actors may attempt to reduce the mobilization capacities of those labor unions and social movements involved in the political struggles of the day. Future research can improve understanding of social mobilization, political behavior, and policy making by identifying new forms of protest avoidance and, perhaps more importantly, by providing further empirical evidence to support this concept.

\section{NOTES}

\footnotetext{
${ }^{1}$ In this article, social mobilization is understood as dialogically tied to the behavior of state actors, whose decisions represent potential "threats" and "opportunities" that may stimulate collective action. On the concept of threat, see McAdam, Tarrow, and Tilly (2001).

${ }^{2}$ This form of politics seems to be particularly present in Continental Europe, especially in centrifugal democracies where the elites are competitive, and the political culture fragmented (Lijphart 1968). In many of these countries, the government can hardly escape blame because its legitimacy is also being questioned on a regular basis.

${ }^{3}$ In France, massive strike activities are possible during the summer; for example, there were massive strikes in August 1953. (Shorter and Tilly 1974: 139-40). At that time, however, paid summer vacations were significantly shorter than today, and labor unions were exceptionally politicized.

${ }^{4}$ On the political opportunity structures approach see, among many available references, Amenta and Zylan (1991); Boudreau (1996); McAdam (1996); Schneider (1997); Tarrow (1996); and Tilly (1978).

${ }^{5}$ Yet, the president is highly influential when his party controls the National Assembly and, thus, forms the government. The president becomes a sort of prime minister because he leads the cabinet.

${ }^{6}$ For a geographical perspective on social movements and contentious politics, see Miller and Martin (2003).

7 "External shocks" like the Great Depression and the terrorist attacks of September 11, 2001 may facilitate the task of state actors promoting the enactment of comprehensive reforms.

${ }^{8}$ French labor unions are not keen on providing scholars with membership data. We would like to thank labor researcher Jean-Marie Pernot for sharing this sensitive data with us.

${ }^{9}$ Such a fragmentation remains an obstacle to the emergence of organizations representing French retirees as a whole (Viriot Durandal 2003).

${ }^{10}$ Unions have not requested managerial control over pensions for public sector employees because they are itemized like wages and are financed via general taxation.
} 
${ }^{11}$ See Bonoli (2000) for a more elaborate discussion on the 1993 reform as well as the debate over the contributive versus non-contributive aspects of pensions.

${ }^{12}$ The CFDT also "obtained" the assurance that the penalty of 10 percent applied to those who retire before 60 years old without a full career would be reduced to 5 percent, and the so-called primes (added wages to the official rank granted to many civil servants, which does not carry benefits) would be taken into account for the calculation of pension benefits.

${ }^{13}$ Schmidt (2002) argues that the Jospin government succeeded in formulating a coherent rationale for "third way" social and economic reforms. Yet, this was hardly the case in the field of pension reform, where labor opposition put the Socialist Party in a very delicate situation that favored stasis, not reform.

\section{REFERENCES}

Amenta, Edwin, and Yvonne Zylan. 1991. "It Happened Here: Political Opportunity, the New Institutionalism, and the Townsend Movement.” American Sociological Review 56: 250-65.

Anderson, Karen, and Traute Meyer. 2003. "Social Democracy, Unions, and Pension Politics in Germany and Sweden.” Journal of Public Policy 23(1): 23-54.

Ashford, Douglas E. 1986. The Emergence of the Welfare States. Oxford: Basil Blackwell.

Baldwin, Peter. 1990. The Politics of Social Solidarity: Class Bases of the European Welfare State 1875-1975. Cambridge: Cambridge University Press.

Béland, Daniel. 2001. "Does Labor Matter? Institutions, Labor Unions and Pension Reform in France and the United States.” Journal of Public Policy 21(2): 153-172.

Birnbaum, Pierre. 1988. States and Collective Action: The European Experience. Cambridge: Cambridge University Press.

Bonoli, Giuliano. 1997. "Pension Politics in France: Patterns of Co-operation and Conflict in Two Recent Reforms.” West European Politics 20(4): 111-124. . 2000. The Politics of Pension Reform. Cambridge: Cambridge University Press.

Boudreau, Vincent. 1996. "Northern Theory, Southern Protest: Opportunity Structure Analysis in CrossNational Perspective.” Mobilization 1(2): 175-189.

Cox, Robert Henry 2001. "The Social Construction of an Imperative: Why Welfare Reform Happened in Denmark and the Netherlands But Not in Germany.” World Politics 53: 463-498.

Culpepper, Pepper D. 2002. "Puzzling, Powering, and 'Pacting': The Informational Logic of Negotiated Reforms.” Journal of European Public Policy 9(5): 774-790.

Edelman, Murray. 1971. Politics as Symbolic Action: Mass Arousal and Quiescence. Chicago: Markham.

Firby, Doug. 2002. “Why Was Calgary So Quiet?” Policy Options (September): 62-64.

Friot, Bernard. 1998. Puissances du salariat: emploi et protection sociale à la francaise. Paris: La Dispute. Guillemard, Anne-Marie. 1986. Le déclin du social. Paris: PUF.

Hay, Colin. 1995. "Structure and Agency.” Pp. 189-206 in Theories and Methods in Political Science, David Marsh and Gerry Stoker, eds. London: MacMillan.

Heclo, Hugh. 1974. Modern Social Politics in Britain and Sweden. New Haven: Yale University Press.

Howard, Dick 1998. "The French Strikes of 1995 and their Political Aftermath.” Government and Opposition (Spring):199-220.

Immergut, Ellen M. 1992. Health Politics: Interests and Institutions in Western Europe. Cambridge: Cambridge University Press.

Join-Lambert, Marie-Thérèse. 1997. Politiques Sociales. Paris: Presses de Sciences Po.

Karila-Cohen, Pierre, and Blaise Wilfert. 1998. Leçon d'histoire sur le syndicalisme en France. Paris: Presses Universitaires de France.

Keeler, John T. S. 1985. "Situating France on the Pluralism-Corporatism Continuum: A Critique of and Alternative to the Wilson Perspective.” Comparative Politics 17(2): 229-249.

King, Desmond, and Randall Hansen. 1999. "Experts at Work: State Autonomy, Social Learning and Eugenic Sterilisation in 1930s Britain.” British Journal of Political Science 29(1): 77-107.

Kingdon, John W. 2003. Agendas, Alternatives, and Public Policies. 2nd ed. New York: Longman.

Lijphart, Arend. 1968. "Typologies of Democratic Systems.” Comparative Political Studies 1(1): 3-44.

Lipset, Seymour Martin. 1983. "Radicalism or Reformism: The Sources of Working-Class Politics." American Political Science Review 77(1): 1-18.

Marier, Patrik. 2002. "Institutional Structure and Policy Change: Pension Reforms in Belgium, France, Sweden and the United Kingdom.” Ph.D. dissertation, University of Pittsburgh.

McAdam, Doug. 1996. "Political Opportunities: Conceptual Origins, Current Problems, Future Direc- 
tions.” Pp. 23-40 in Comparative Perspectives on Social Movements, Doug McAdam, John D. McCarthy, and Mayer Zald, eds. Cambridge: Cambridge University Press.

McAdam, Doug, Sidney Tarrow, and Charles Tilly. 2001. Dynamics of Contention. New York: Cambridge University Press.

Meyer, David S., and Debra C. Minkoff. 2004. “Conceptualizing Political Opportunity.” Social Forces 82(4): 1457-1492.

Miller, Byron, and Deborah G. Martin. 2003. “Space and Contentious Politics.” Mobilization 8(2): 143-156.

Miura, Mari, and Bruno Palier. 2003. "Veto Players and Welfare Reform: The Paradox of French and Japanese Unions.” Paper presented at the annual meeting of the American Political Science Association, Philadelphia, PA, August 27-September 1.

Mouriaux, René, and Françoise Subileau. 1996. "Les grèves françaises de l'automne 1995: défense des acquis ou mouvement social?” Modern and Contemporary France NS4(3): 299-306.

Myles, John, and Paul Pierson. 2001. "The Political Economy of Pension Reform.” Pp. 305-333 in The New Politics of the Welfare State, Paul Pierson, ed. Oxford: Oxford University Press.

Natali, David, and Martin Rhodes. 2004. "Trade-Offs and Veto Players: Reforming Pensions in France and Italy.” French Politics 2(1): 1-23.

Palier, Bruno. 1999. "Réformer la sécurité sociale: les interventions gouvernementales en matière de protection sociale depuis 1945, la France dans une perspective comparative.” Ph.D. dissertation, Political Science, Institut d'Etudes Politiques.

Petry, François, Louis M. Imbeau, Jean Crête, and Michel Clavet. 1999. "Electoral and Partisan Cycles in the Canadian Provinces.” Canadian Journal of Political Science 32(2): 273-292.

Pierson, Paul. 1993. "When Effect Becomes Cause: Policy Feedback and Political Change.” World Politics 45 (July): 595-628.

1994. Dismantling the Welfare State? Cambridge: Cambridge University Press.

. 1996. "The New Politics of the Welfare State.” World Politics 48 (January):143-179. , ed. 2001. The New Politics of Welfare State. Oxford: Oxford University Press.

Pitruzzello, Salvatore. 1997. "Social policy and the Implementation of the Maastricht Fiscal Convergence Criteria: The Italian and French Attempts at Welfare and Pension Reforms.” Social Research 64(4): 1589-1642.

Piven, Frances Fox, and Richard Cloward. 1971. Regulating the Poor: The Functions of Public Welfare. New York: Pantheon.

Powell, G. Bingham. 2000. Elections as Instruments of Democracy: Majoritarian and Proportional Visions. New Haven: Yale University Press.

Renard, Didier. 1999. "Dire, faire, faire croire: changements de vocabulaire et changements de politiques: la réforme des retraites en France.” Lien Social et Politiques - RIAC 41 (Spring): 71-85.

Rokkan, Stein. 1999. "State Formation and Nation-Building.” Pp. 93-224 in State Formation, NationBuilding, and Mass Politics in Europe, Stein Kuhnle, Peter Flora and Derek Urwin, eds. Oxford: Oxford University Press.

Ross, Fiona. 2000. “Interests and Choice in the 'Not Quite so New’ Politics of Welfare.” West European Politics 23: 11-34.

Ruellan, Rolande. 1993. “Retraites: l’impossible réforme est-elle achevée.” Droit Social 12: 911-129.

Schmidt, Vivien A. 2002. "Does Discourse Matter in the Politics of Welfare State Adjustment?" Comparative Political Studies 35(2): 168-193.

Schneider, Cathy. 1997. "Framing Puerto Rican Identity: Political Opportunity Structures and Neighborhood Organizing in New York City.” Mobilization 2(2): 227-245.

Shorter, Edward, and Charles Tilly. 1974. Strikes in France, 1830-1968. Cambridge: Cambridge University Press.

Tarrow, Sidney. 1996. "States and Opportunities: The Political Structuring of Social Movements.” Pp. 41-61 in Comparative Perspectives on Social Movements, Doug McAdam, John D. McCarthy, and Mayer Zald, eds. Cambridge: Cambridge University Press.

Tilly, Charles. 1978. From Mobilization to Revolution. New York: McGraw-Hill.

. 1986. The Contentious French. Cambridge: Harvard University Press.

Vail, Mark I. 1999. “The Better Part of Valour: The Politics of French Welfare Reform.” Journal of European Social Policy 9(4): 311-329.

Viriot Durandal, Jean-Philippe. 2003. Le pouvoir gris: sociologie des groupes de pression de retraités. Paris: Presses Universitaires de France.

Weaver, R. Kent. 1986. “The Politics of Blame Avoidance.” Journal of Public Policy 6 (OctoberDecember): 371-398. 